\title{
Identification and characterization of pathogenic Pestalotiopsis species to pecan tree in Brazil
}

\author{
Marília Lazarotto(1), Marciéli Pitorini Bovolini(2), Marlove Fátima Brião Muniz(2), Ricardo Harakawa(3), \\ Lia Rejane Silveira Reiniger ${ }^{(4)}$ and Álvaro Figueredo dos Santos ${ }^{(5)}$
}

\begin{abstract}
(1)Universidade Federal do Rio Grande do Sul, Departamento de Horticultura e Silvicultura, Avenida Bento Gonçalves, no 7.712, CEP 91501-970 Porto Alegre, RS, Brazil. E-mail: lilalazarotto@yahoo.com.br (2)Universidade Federal de Santa Maria, Departamento de Defesa Fitossanitária, Avenida Roraima, № 1.000, CEP 97105-900 Santa Maria, RS, Brazil. E-mail: maninhabovolini@yahoo.com.br, marlovemuniz@yahoo.com.br (3)Instituto Biológico de São Paulo, Avenida Conselheiro Rodrigues Alves, oo 1.252, CEP 04014-002 São Paulo, SP, Brazil. E-mail: harakava@biologico.sp.gov.br (4)Universidade Federal de Santa Maria, Departamento de Fitotecnia, Avenida Roraima, no 1.000, CEP 97105-900 Santa Maria, RS, Brazil. E-mail: liarsr@ufsm.br ${ }^{(5)}$ Embrapa Florestas, Estrada da Ribeira, Km 111, Caixa Postal 319, CEP 83411-000 Colombo, PR, Brazil. E-mail: alvaro.santos@embrapa.br
\end{abstract}

Abstract - The objective of this work was to characterize and cluster isolates of Pestalotiopsis species and to identify those that are pathogenic to pecan, based on morphological and molecular characters. Pestalotiopsis spp. isolates were identified by sequencing the internal transcribed spacer (ITS) and $\beta$-tubulin regions. Identification methods were compared to indicate the key morphological characters for species characterization. Thirteen isolates were used for the pathogenicity tests. Morphological characterization was performed using the following variables: mycelial growth rate, sporulation, colony pigmentation, and conidial length and width. Ten pathogenic isolates were identified, three as Pestalotiopsis clavispora and three as P. cocculi. The other isolates remained as an undefined species. The morphological characters were efficient for an initial separation of the isolates, which were grouped according to differences at species level, mainly colony diameter, which was identified as an important morphological describer. Beta-tubulin gene sequencing was less informative than the ITS region sequencing for species identification.

Index terms: Carya illinoinensis, $\beta$-tubulin, ITS rDNA, morphological characters, phylogeny, UPGMA.

\section{Identificação e caracterização de espécies de Pestalotiopsis patogênicas à nogueira-pecã no Brasil}

Resumo - O objetivo deste trabalho foi caracterizar e agrupar isolados de espécies de Pestalotiopsis e identificar aquelas patogênicas à nogueira-pecã, com base em caracteres morfológicos e moleculares. Os isolados de Pestalotiopsis spp. foram identificados por meio do sequenciamento das regiões internal transcribed spacer (ITS) e $\beta$-tubulina. Os métodos de identificação foram comparados, para indicar os caracteres morfológicos chave para a caracterização das espécies. Treze isolados foram utilizados para os testes de patogenicidade. A caracterização morfológica foi realizada com a utilização das seguintes variáveis: taxa de crescimento micelial, esporulação, pigmentação das colônias, comprimento e largura de conídios. Dez isolados patogênicos foram identificados, três como Pestalotiopsis clavispora e três como $P$. cocculi. Os outros isolados permaneceram como espécie não definida. Os caracteres morfológicos foram eficientes na separação inicial dos isolados, os quais foram agrupados por diferenças quanto à espécie, principalmente o diâmetro das colônias, identificado como um importante descritor morfológico. O sequenciamento do gene da $\beta$-tubulina foi menos informativo do que o sequenciamento da região ITS para a identificação de espécies.

Termos para indexação: Carya illinoinensis, $\beta$-tubulina, rDNA ITS, caracteres morfológicos, filogenia, UPGMA.

\section{Introduction}

Pecan (Carya illinoinensis [Wangenh.] K. Koch) belongs to the Juglandaceae family and is one of the few agronomically important nut species native to North America (Bonito et al., 2011). Juglandaceae comprises only six genera and approximately
100 medium to large-sized tree species. There are more than 1,000 pecan cultivars that show variation in fruit forms, nut quality, tree architecture, and reproductive characteristics. This fact is due to the high level of genetic segregation because of seed multiplication, which is the major propagation method for pecan tree (Almeida et al., 2002). Pecan-producing area has 
been growing in southern Brazil; as a consequence, an increased incidence of diseases caused by fungi, bacteria or other microorganisms has been observed in these areas.

A new type of leaf spot disease associated to Pestalotiopsis genus fungi has been occurring in the state of Rio Grande do Sul, Brazil. In severe cases, it culminates in fallen leaves and nut production losses, due to a decrease of photosynthetic area (Lazarotto et al., 2012). This pathogen has not yet been reported on pecan; however, it causes significant problems in other species of economic importance as observed for: P. microspora as a causal agent of nut black spot in Carya cathayensis (Chuanqing et al., 2010); P. clavispora causing scab disease in Psidium guajava, in Hawaii (Keith et al., 2006), and as causal agent of leaf blotch in Rosa chinensis, in China (Feng et al., 2014); and Pestalotiopsis spp. causing leaf spot in Vigna unguiculata, in India (Mahadevakumar \& Janardhana, 2014). The morphological and molecular recognition and identification of these organisms are important for creating a database for future, fast, and accurate identification.

Knowledge of the morphological and physiological characteristics of the colonies, mycelia, and conidia of a pathogenic fungus is crucial to develop studies on such microorganism (Dhingra \& Sinclair, 1995). The morphological characters, mainly the conidia ones, could be useful for species differentiation in Pestalotiopsis (Maharachchikumbura et al., 2011). However, in many genera, these characters are difficult to observe in natural populations and are often affected by environmental factors (Faleiro et al., 2003).

The best manner to identify fungi is to use the phylogenetic species concept by the phylogenetic analysis of variable characteristics of multiple gene genealogies (Taylor et al., 2000). The most common region used for molecular identification of fungi is the internal transcribed spacer (ITS) in the ribosomal RNA gene structure, which is divided into $18 \mathrm{~S}, 5.8 \mathrm{~S}$, and $28 \mathrm{~S}$, as well as in ITS1 and ITS2 regions. The highly conserved genes $18 \mathrm{~S}, 5.8 \mathrm{~S}$, and $28 \mathrm{~S}$ allow of the design of panfungal primers, which occur in tandem with the least conserved ITS1 and ITS2 regions that are more species-specific. On the last affirmation, Reis Junior et al. (2006) reported that these genes have many phylogenetically conserved sequences and, therefore, are well suited for biodiversity studies. Another advantage of using RNAr is the available data, which allows of comparison of sequences (Coutinho et al., 1999). However, sequencing only one region is often insufficient for species-level identification, and $\mathrm{Hu}$ et al. (2007) suggested that at least two genes should be used to determine the phylogeny of Pestalotiopsis species.

The objective of this work was to characterize and cluster isolates of Pestalotiopsis species, and to identify those that are pathogenic to pecan, based on morphological and molecular characters.

\section{Materials and Methods}

Symptomatic samples were collected from pecan orchards in different municipalities of the state of Rio Grande do Sul, Brazil. All collection points were georeferenced using the global positioning system (GPS), according to Table 1.

Leaves collected in the field were identified. After pathogen detection, pathogen structures were transferred to Petri dishes containing potato dextrose agar (PDA) culture media using a histology needle in a laminar flow hood (Alfenas et al., 2007). After ten days of growth, the cultured isolates were purified through monosporic isolation and stored under conditions of 12 hour light-dark cycles, at $25^{\circ} \mathrm{C} \pm 2^{\circ} \mathrm{C}$, for subsequent use.

For spore suspension preparation, fungi cultures were grown on PDA and, after 15 days of growth, $20 \mathrm{~mL}$ of distilled water were added to each plate; then, the surface of the medium was scraped with a glass rod, and the suspension was drained into a beaker. Spore concentration was evaluated with a Neubauer chamber, and a concentration of $2 \times 10^{6}$ spores $\mathrm{mL}^{-1}$ was adopted.

All 16 collected isolates were tested. Inoculation was performed by spraying the suspension on leaves of pecan seedlings. Plants remained for 72 hours in a humid chamber (covered with plastic and with a source of moisture), under $50 \%$ shade and daily irrigation until the assessments. Eight seedlings from seed divided into four replicates of two plants for each isolate and for the control treatment were used. After symptom expression, isolation was carried out in order to confirm the genus identification. The assessments were performed after 45 days, and disease incidence (\%) was assessed for each isolate, with subsequent pathogen re-isolation in PDA medium to fulfill Koch's postulates and to identify the species morphologically and genetically. 
The morphological characterization was performed, and ten Pestalotiopsis spp. isolates were identified as being pathogenic to pecan tree. Procedures were based on the methodology of Michereff et al. (2003), in which each isolate was evaluated using mycelial growth rate, sporulation, colony pigmentation, and conidial length, described as follows. Mycelial growth rate was assessed by transferring $6 \mathrm{~mm}$ diameter PDA medium disks, derived from seven-day old colonies, into other PDA medium plates, including four replicates for each isolate and assessing colony growth daily until the seventh day of incubation by averaging the colony's diameter in diametrically opposite directions. Sporulation was evaluated on day 10 of incubation by adding $20 \mathrm{~mL}$ of sterile distilled water to each plate used to evaluate mycelial growth, and conidial concentration was estimated by scraping the colonies and sieving through a double layer of gauze (conidia $\mathrm{mL}^{-1}$ ) using a Neubauer chamber. Colony pigmentation was based on the observation and recording of colonies and aerial mycelium pigmentation. Conidial length and width were assessed from a sample from the fungal conidia suspension in sterile distilled water $(2 \mathrm{~mL})$, which was pipetted onto a microscope slide. Conidia were measured using a light microscope with a micrometer at 40X magnification. Thirty conidia were measured for each isolate. The number of cells and the number of conidia filiform appendages were also counted.

Molecular characterization was also carried out with the ten pathogenic Pestalotiopsis spp. isolates. Pathogen DNA extraction was performed according to the cetyltrimethylammonium bromide (CTAB) method described by Doyle \& Doyle (1991). Extracted genomic DNA samples were analyzed by polymerase chain reaction (PCR) to amplify the rDNA ITS region using the ITS1 (5'-TTCCGTAGGTGAACCTGCGG-3') and ITS4 (5'-TCCTCCGCTTATTGATATGC-3') primers (White et al., 1990), as well as to amplify $\beta$-tubulin region using the Btub-F (AAGGGHCAYTAYACYGARGG) and Btub-R (CATGTTGGACTCDGCCTC) primers.
The reaction contained approximately $30 \mathrm{ng}$ DNA, $10 \mathrm{X}$ buffer, $2.5 \mu \mathrm{mol} \mathrm{L} \mathrm{L}^{-1}$ of each dNTP, $20 \mathrm{nmol} \mathrm{L}^{-1}$ $\mathrm{MgCl}_{2}, 25$ pmol of each primer, and five units of Taq polymerase enzyme; the reaction was brought to a volume of $25 \mu \mathrm{L}$ using ultrapure water. The reactions were performed in a MJ Research PTC-100 thermocycler (MT Research Inc., Las Vegas, NV, USA) under the following thermal conditions: $94^{\circ} \mathrm{C}$ for $2 \mathrm{~min}$; 30 cycles of $94^{\circ} \mathrm{C}$ for $45 \mathrm{~s}, 55^{\circ} \mathrm{C}$ for $30 \mathrm{~s}$, and $72^{\circ} \mathrm{C}$ for $35 \mathrm{~s}$; and finally $72^{\circ} \mathrm{C}$ for $10 \mathrm{~min}$. PCR products were stored at $4^{\circ} \mathrm{C}$ upon the completion of the reaction. A negative control without DNA was included in the PCR amplifications. The amplified fragments and control were separated by $1.2 \%$ agarose gel electrophoresis in $1 \mathrm{X}$ TBE buffer (10.8 g TRIS base, $5.5 \mathrm{~g}$ boric acid, $4 \mathrm{~mL} 0.5 \mathrm{~mol} \mathrm{~L}^{-1}$ EDTA, and $4 \mathrm{~mL}$ distilled water) containing ethidium bromide, and both were visualized under ultraviolet light by AlphaImager TM 1220 (Alpha Innotech Corporation, San Leandro, CA, USA).

The PCR products were purified using 13\% PEG 8000 and the described primers were used in the sequencing reactions. Sequencing was performed on a Mega Bace 500 Sequencer (GE Healthcare Life Sciences, Pittsburgh, PA, USA). The sequenced fragments were analyzed using the BioEdit software (Hall, 1999). The obtained nucleotide sequences of the isolated pathogens were compared with those previously deposited in the GenBank (National Center for Biotechnology Information, 2012b). Nucleotide sequence similarity between the isolates was calculated using the basic local alignment search tool (BLAST, National Center for Biotechnology Information, 2012a) procedure. All isolate sequences were subjected to the GenBank, and the accession codes were inserted on the tree.

The GenBank sequences with the highest "scores" (more than $98 \%$ of similarity and coverage) were selected and aligned with the sequences found in sequencing, using the ClustalW algorithm, and a phylogenetic analysis was conducted by the

Table 1. Information about collection locations of Pestalotiopsis spp. isolates derived from pecan tree (Carya illinoinensis) orchards in the state of Rio Grande do Sul, Brazil.

\begin{tabular}{|c|c|c|c|c|}
\hline Municipality & Collection date & Coordinates (GMS) & Altitude (m) & Isolates \\
\hline Anta Gorda & Jan./2010 & $28^{\circ} 53^{\prime} 55^{\prime \prime} \mathrm{S}, 52^{\circ} 02^{\prime} 0^{\prime \prime} \mathrm{W}$ & 514 & $\mathrm{P}_{1}, \mathrm{P}_{2}, \mathrm{P}_{3}, \mathrm{P}_{9}, \mathrm{P}_{10}, \mathrm{P}_{14}$ \\
\hline Santa Maria & Nov./2010 & $29^{\circ} 43^{\prime} 13^{\prime \prime S}, 53^{\circ} 43^{\prime} 2^{\prime \prime} \mathrm{W}$ & 88 & $\mathrm{P}_{5}$ \\
\hline Santana do Livramento & Mar./2011 & $30^{\circ} 52^{\prime} 9^{\prime \prime} \mathrm{S}, 55^{\circ} 27^{\prime} 28^{\prime \prime} \mathrm{W}$ & 212 & $\mathrm{P}_{16}$ \\
\hline Santa Rosa & Jun./2011 & $27^{\circ} 55^{\prime} 13^{\prime \prime S}, 54^{\circ} 32^{\prime} 51^{\prime \prime} \mathrm{W}$ & 268 & $\mathrm{P}_{11}$ \\
\hline Sentinela do Sul & Mar./2011 & $30^{\circ} 34^{\prime} 36^{\prime \prime} \mathrm{S}, 51^{\circ} 31^{\prime} 45^{\prime \prime} \mathrm{W}$ & 101 & $\mathrm{P}_{7}$ \\
\hline
\end{tabular}

Pesq. agropec. bras., Brasília, v.49, n.6, p.440-448, jun. 2014

DOI: 10.1590/S0100-204X2014000600005 
neighbor-joining statistical method with 1,000 replicates and the Mega software, version 4.0 (Tamura et al., 2007). The model was selected using the FindModel software, which establishes the best model based on a file with the chosen, aligned sequences using BioEdit (Hall, 1999). Quantitative data on morphological characterization were subjected to a multivariate analysis technique for a cluster analysis of the isolates. These analyses were performed using the Genes software (version 2009.7.0). The array of standardized Euclidean distances (D2) was calculated as a dissimilarity measure and was used to cluster the isolates according to the unweighted pair group method with arithmetic mean (UPGMA) method (Cruz, 2008).

\section{Results and Discussion}

In the state of Rio Grande do Sul, the isolates $\mathrm{P}_{1}$, $\mathrm{P}_{2}, \mathrm{P}_{3}, \mathrm{P}_{9}, \mathrm{P}_{10}$, and $\mathrm{P}_{14}$ (collected in Anta Gorda), $\mathrm{P}_{5}$ (collected in Santa Maria), $\mathrm{P}_{7}$ (collected in Sentinela do Sul), $\mathrm{P}_{11}$ (collected in Santa Rosa), and $\mathrm{P}_{16}$ (collected in Santana do Livramento) were pathogenic to pecan seedlings. The leaf symptoms of seedlings, as previously observed in the field, began approximately 13 days after inoculation and were described as follows: small dark brown spots expanded to become gray/light brown circles surrounded by a dark brown border; and dark spots in the center of the lesion, corresponding to the development of pathogen exuding conidia (cirrus). The other six isolates were not pathogenic; therefore, morphological and molecular characterization were not performed for them. All these isolates were initially identified as belonging to the Pestalotiopsis genus by morphological observation of conidia.

In severe cases, lesions were observed on large portions of a single leaf and multiple lesions were common, which coalesced to form an overall scabbed appearance, culminating in fallen leaves (Figure 1). Until present, no report was found on the occurrence of organisms belonging to Pestalotiopsis genus causing leaf spots in pecan tree, as described in the present work. Chuanqing et al. (2010) identified P. microspora as a causal agent of nut black spot on $C$. cathayensis in China, which is a tree species of the same genus and a nut producer as well.

Colony diameters ranged from $53.43 \mathrm{~mm}\left(\mathrm{P}_{5}\right)$ to $65.47 \mathrm{~mm}\left(\mathrm{P}_{1}\right)$, and some isolates showed faster daily mycelial growth rate (MGR), such as $\mathrm{P}_{1}$ following
$\mathrm{P}_{2}$ and $\mathrm{P}_{14}$, with MGR greater than $9.0 \mathrm{~mm}$, whereas some isolates $\left(\mathrm{P}_{3}, \mathrm{P}_{5}\right.$, and $\left.\mathrm{P}_{10}\right)$ exhibited the lowest (inferior to $8.0 \mathrm{~mm}$ ) MGR (Table 2). Sporulation ranged from $2.64 \times 10^{6}\left(\mathrm{P}_{5}\right)$ to $10.0 \times 10^{6}$ spores per millimeter $\left(\mathrm{P}_{16}\right)$, although this character is influenced by culture media and environmental conditions. However, in this case, this is not the reason for these differences among isolates because all of them were cultivated in the same media and growing conditions; therefore, variation could be related to the genetic variability between different species or to intraspecific variability. Conidia dimensions ranged in length from 25.12 to $32.12 \mu \mathrm{m}$ and in width from 5.60 to 7.88 $\mu \mathrm{m}$. The number of conidia cells ranged from five to six, and the terminal filiform appendage number ranged from two to four. Apical appendage length and number are also widely used characters for species identification (Maharachchikumbura et al., 2011). All colonies showed similar pigmentation, tending to white (mycelia) with black droplets in the center, corresponding to the development of pathogen exuding conidia. Regarding the morphological characterization of Pestalotiopsis spp. isolates, $\mathrm{Hu}$ et al. (2007) and Liu et al. (2010) found that the morphology varies

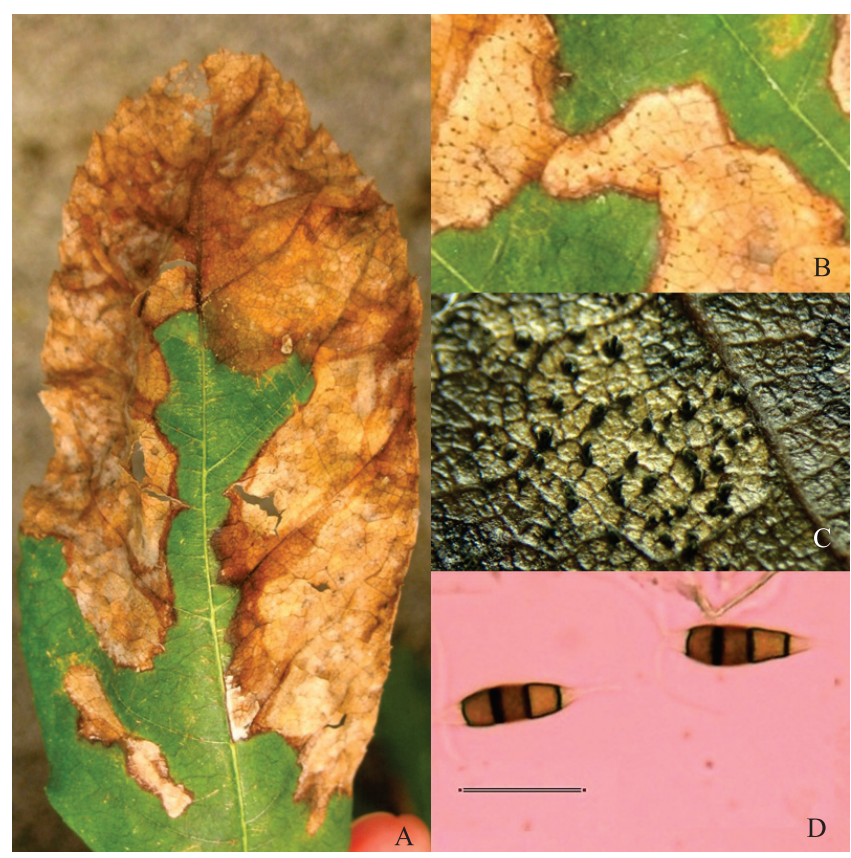

Figure 1. Pathogenicity test of Pestalotiopsis spp. isolates. Leaf spot after $\mathrm{P}_{7}$ isolate inoculation (A); leaf spot detail (B); pathogen exuding conidia (cirrus) detail (C); conidia observed in a microscope with 40X magnification (D). 
inter- and intraspecies and should be interpreted with caution; therefore, it can be a way to differ isolates, but a complementary analysis is necessary.

Wei \& Xu (2004) identified P. kunmingensis as a Podocarpus macrophyllus endophyte organism. These authors highlighted that, despite the huge divergences to classify Pestalotia sp. or Pestalotiopsis sp., the latter usually has some specific morphological and physiological characteristics, such as: fusiform conidia formed within compact acervuli; conidia with usually five cells, with three colored median cells, and two colorless end cells; and conidia with two or more apical appendages arising from the apical cell. Liu et al. (2007) used the following characters for the morphological description of $P$. hainanensis isolates: size, length, and width of conidia; median cell color; number, position, and length of apical appendage; apical appendage tip (branched or unbranched); basal appendage presence/absence of basal appendage; and fungi habit. Results found by these authors are an indicative that some morphological characters have major impact on isolate differentiation, and could be used for an initial division among them to identify different species and to conduct pathogenic studies.

Analyzing the tree generated by the UPGMA clustering method, the smallest dissimilarities were found between isolates $\mathrm{P}_{3}$ and $\mathrm{P}_{10}$, followed by $\mathrm{P}_{1}$ and $\mathrm{P}_{2}$, and the clustering between these pairs of isolates showed dissimilarities below 20\% (Figure 2). When $\mathrm{P}_{5}$ was clustered to $\mathrm{P}_{3}$ and $\mathrm{P}_{10}$, dissimilarities were of about $30 \%$, and when $\mathrm{P}_{14}$ was clustered to $\mathrm{P}_{1}$ and $\mathrm{P}_{2}$, of about $40 \%$. Isolates $\mathrm{P}_{7}$ and $\mathrm{P}_{11}$, despite belonging to the same group, showed dissimilarity over $50 \%$, representing a higher difference between them. $\mathrm{P}_{16}$ seems to be the major distinct isolate, since it stayed more disconnected, showing dissimilarity of about $80 \%$ from the others.

Multivariate analysis also provided the relative contributions of each of the characteristics to divergence: colony diameter, sporulation, conidia length, and conidia width were responsible for 64.1, 20.5, 14.1, and 1.3\%, respectively (Figure 2). This result indicates that the differentiation of the Pestalotiopsis spp. isolates into the groups formed in the tree was mainly due to the colony diameter characteristic. Souza et al. (2007) identified the shape of Colletotrichum lindemuthianum conidia as a morphological marker that could be used for genetic analyses; Alves et al. (2008) studied a collection of isolates, identified as Lasiodiplodia theobromae, and potential cryptic species based on differences in conidial morphology and on sequence data from the ITS regions and EF1- $\alpha$ gene; and Jeewon et al. (2004) reported that, for Pestalotiopsis species, the pigmentation of median cells and morphology of apical appendages are the most import characters to distinguish groups. These reports corroborate the studies of Wei \& Xu (2004) and Liu et al. (2007), who used morphological characters as markers for species or isolate differentiation.

Morphological characterization is very useful in the identification and distinction of isolates; however, morphological and molecular identification allows of a greater reliability, when data from both methods are compared. In recent years, studies involving the identification of fungal isolates have attempted

Table 2. Characteristics of the colonies and conidia of pathogenic Pestalotiopsis species to pecan tree (Carya illinoinensis) grown in potato dextrose agar (PDA) media.

\begin{tabular}{|c|c|c|c|c|c|c|c|}
\hline \multirow[t]{2}{*}{ Isolates } & \multirow{2}{*}{$\begin{array}{l}\text { Diameter }^{(1)} \\
(\mathrm{mm})\end{array}$} & \multirow{2}{*}{$\begin{array}{c}\text { MGR }^{(2)} \\
\text { (mm per day) }\end{array}$} & \multirow{2}{*}{$\begin{array}{c}\text { Sporulation } \\
\left(\times 10^{6} \text { spores } \mathrm{mL}^{-1}\right)^{(3)}\end{array}$} & \multicolumn{4}{|c|}{ Conidia } \\
\hline & & & & Length $(\mu \mathrm{m})$ & Width $(\mu \mathrm{m})$ & Cell number & Appendage number \\
\hline$\overline{P_{1}}$ & $65.47(1.41)$ & $9.35(0.81)$ & $7.45(1.65)$ & $29.13(0.76)$ & $7.88(0.26)$ & 5 & $2-3$ \\
\hline $\mathrm{P}_{2}$ & $65.07(1.20)$ & $9.29(0.37)$ & $7.64(0.78)$ & $28.88(0.82)$ & $7.5(0.55)$ & 6 & $2-3$ \\
\hline $\mathrm{P}_{3}$ & $54.62(0.61)$ & $7.80(0.15)$ & $2.78(0.17)$ & $32.00(0.85)$ & $7.37(1.24)$ & 6 & $2-3$ \\
\hline $\mathrm{P}_{5}$ & $53.43(0.33)$ & $7.63(0.18)$ & $2.64(0.14)$ & $31.00(0.97)$ & $6.88(0.66)$ & 6 & $2-3$ \\
\hline $\mathrm{P}_{7}$ & $56.30(1.53)$ & $8.04(0.37)$ & $6.81(0.57)$ & $27.12(0.75)$ & $5.60(0.55)$ & 6 & $2-3$ \\
\hline $\mathrm{P}_{9}$ & $56.00(1.62)$ & $8.00(0.23)$ & $4.04(0.07)$ & $28.12(0.68)$ & $7.12(0.47)$ & 6 & $2-3$ \\
\hline $\mathrm{P}_{10}$ & $55.61(0.32)$ & $7.94(0.15)$ & $2.95(0.05)$ & $30.75(1.25)$ & $7.45(0.73)$ & 5 & $2-3$ \\
\hline $\mathrm{P}_{11}$ & $57.25(1.05)$ & $8.18(0.15)$ & $4.13(0.22)$ & $26.12(0.70)$ & $6.35(0.52)$ & 5 & $2-3$ \\
\hline $\mathrm{P}_{14}$ & $64.50(0.48)$ & $9.21(0.27)$ & $7.68(0.29)$ & $29.00(0.85)$ & $6.87(0.52)$ & 5 & $2-4$ \\
\hline $\mathrm{P}_{16}$ & $60.09(0.56)$ & $8.58(0.29)$ & $10.01(0.56)$ & $25.12(0.93)$ & $7.00(0.57)$ & $5-6$ & $2-3$ \\
\hline
\end{tabular}

${ }^{(1)}$ Diameter, colony diameter in the seventh day. Maximum diameter of Petri plate is $90 \mathrm{~mm}$. ${ }^{(2)} \mathrm{MGR}$, daily mycelial growth rate calculated using the colony diameter at the final assessment day. ${ }^{(3)}$ Potato-dextrose-agar culture medium. Values in parentheses indicate standard deviation. 
to combine identifications by morphological and molecular characteristics. Andrade et al. (2007) conducted a study aiming at characterizing the morphological, cultural, and pathogenic variability of Colletotrichum gloeosporioides samples isolated from papaya tree (Carica papaya), and isolates were separated into groups according to colony color. Subsequently, isolates were molecularly identified by PCR using taxon-specific primers and PCR-restriction fragment length polymorphism (PCR-RFLP) analysis of the ITS region, combining morphological and molecular techniques, as those performed in the present study.

The alignment of the isolate sequences found in the present study with those deposited in the GenBank shows that isolates can be grouped according to their phylogenetic similarity, corroborating some results observed in a previous tree regarding morphological characters (Figure 2). The phylogenetic tree resulted from the alignment of the ITS and $\beta$-tubulin sequences from all Pestalotiopsis spp. pathogenic isolates with the database sequences of the highest similarity (Figure 3). Based on ITS sequences, isolates $\mathrm{P}_{1}, \mathrm{P}_{2}$, and $\mathrm{P}_{14}$ were grouped in the same clade as the $P$. oxyanth and $P$. mangiferae sequences; therefore, it was not possible to identify the exact species. These isolates were grouped into the same clade in the tree based on morphological characters (Figure 2). $\mathrm{P}_{3}, \mathrm{P}_{5}$, and

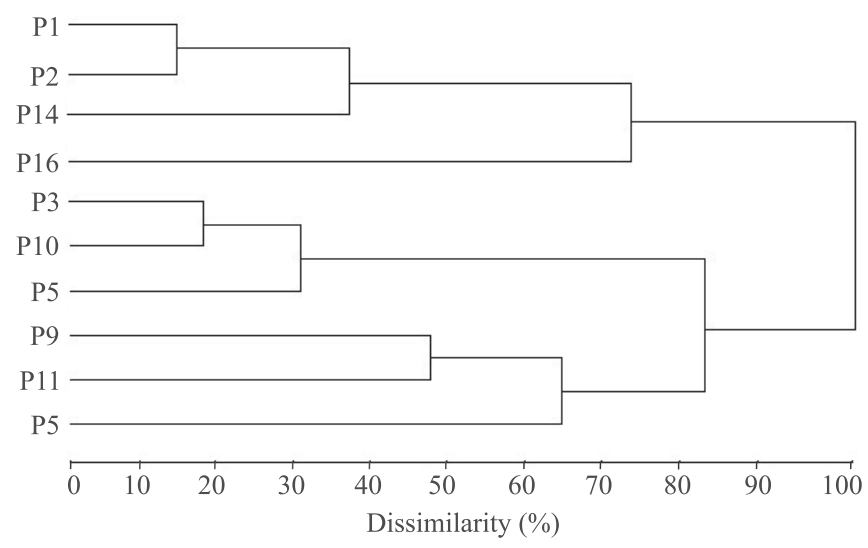

Figure 2. Tree showing the percentage of dissimilarity between Pestalotiopsis spp. isolates that are pathogenic to pecan (Carya illinoinensis). The tree was designed using the unweighted pair group method with arithmetic mean (UPGMA) method, based on a Euclidean distance matrix analysis using four morphological characteristics: colony diameter, sporulation, and conidial length and width.
$\mathrm{P}_{10}$ were grouped in the same clade as the sequences of $P$. clavispora, and $\mathrm{P}_{3}$ and $\mathrm{P}_{10}$ were closer to each other, indicating a greater genetic proximity than $\mathrm{P}_{5}$. These isolates $\left(\mathrm{P}_{3}, \mathrm{P}_{5}\right.$, and $\left.\mathrm{P}_{10}\right)$ were identified as to species level because they showed high similarity with P. clavispora sequences (over 99\%) and were also grouped in the same clade by phylogenetic analysis; however, $\mathrm{P}_{5}$ remained as an undefined species.

Isolates $\mathrm{P}_{7}, \mathrm{P}_{9}$, and $\mathrm{P}_{11}$ had a greater similarity with $P$. cocculi sequences, based on ITS sequences, although $P$. vismiae also clustered in the same clade, due to its genetic similarity. However, the similarity values were higher for $P$. cocculi sequences, and the isolates $\mathrm{P}_{7}$ and $\mathrm{P}_{11}$ were closer to a specific sequence of $P$. cocculi (EF055193) than the others. Hu et al. (2007) also studied the phylogenetic diversity of endophytic Pestalotiopsis species in Pinus armandii and Ribes spp., based on the ITS and $\beta$-tubulin genes, and found that both species grouped in the same clade, sharing similar morphological characters. However, $\mathrm{P}_{16}$ could not be identified at species level by ITS sequencing, since it grouped with $P$. mangiferae, $P$. micropora, and P. clavispora. This last isolate is also distant from the others, based on morphological characters (Figure 2).

Some of the species identified in the present study have been reported to be pathogenic in other plant hosts. Keith et al. (2006) found P. clavispora as the causal agent of scab disease in guava (Psidium guajava) in Hawaii. This species was also the causal agent of blueberry (Vaccinium spp.) canker in Chile, identified by Espinoza et al. (2008). Maharachchikumbura et al. (2011) considered the species as one of the greatest economic importance, since it is pathogenic to several hosts. Chen et al. (2012) reported P. mangiferae and $P$. vismiae as causal agents of twig dieback of Myrica rubra in China, and Jeewon et al. (2004) identified $P$. vismiae as a causal agent of leaf spot in Leucospermum sp. in Hawaii. Other species have been reported as endophytic organisms, which is a common occurrence within genus. P. oxyanthi was identified by Wei et al. (2007) as a pathogenic fungus and an endophyte in Podocarpus macrophyllus, and only as an endophyte in Camellia nitidissima. Hu et al. (2007) detected $P$. cocculi as an endophytic organism in bark and needles of Pinus armandii, as well as in leaves of Ribes spp.; these authors also identified $P$. vismiae in bark of $P$. armandii in China.

Pesq. agropec. bras., Brasília, v.49, n.6, p.440-448, jun. 2014 DOI: 10.1590/S0100-204X2014000600005 
The ITS gene is often used in the molecular characterization of Pestalotiopsis spp., as confirmed by Patel et al. (2013), using the ITS region to identify P. mangiferae as the causal agent of canker in Ulmus parvifolia in the United States; by Mahadevakumar \& Janardhana (2014), for Pestalotiopsis spp. causing leaf spot in Vigna unguiculata; and by Jeon \& Cheon (2014), for the identification of P. microspora, causal agent of leaf blight in Taxus cuspidate, in Korea. However, $\mathrm{Hu}$ et al. (2007) pointed out that the $\beta$-tubulin genes resolve Pestalotiopsis phylogeny better than the ITS gene. A combination of both $\beta$-tubulin and ITS genes gave a better phylogenetic resolution.
Based on the $\beta$-tubulin sequences, $\mathrm{P}_{1}, \mathrm{P}_{2}$, and $\mathrm{P}_{14}$ were clustered in the same clade as they were on the tree constructed through ITS sequencing (Figure 3). However, species identification was not possible, as they were in a different clade from the sequences that showed high similarity $(P$. virgatula, $P$. palmarum, and $P$. gracilis). Therefore, the sequencing of the $\beta$-tubulin gene was not informative for these isolates, since with ITS sequencing, they were identified between $P$. oxyanthi and P. mangiferae; however, these species were not showed by $\beta$-tubulin gene sequencing. Probably, this happened because, for this gene, there are no deposited sequences on the GenBank of these two specific species yet ( $P$. oxyanthi and $P$. mangiferae).

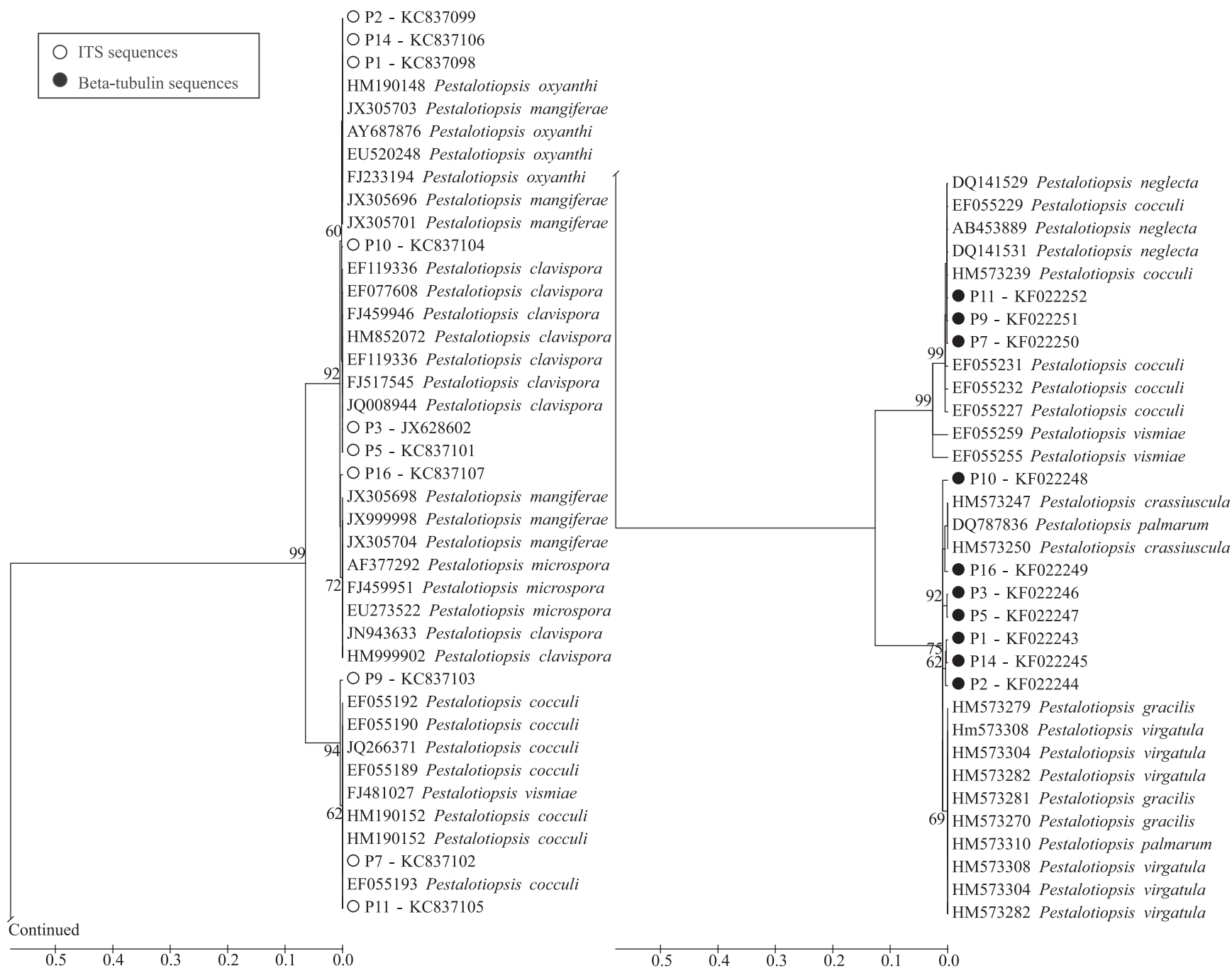

Figure 3. Phylogenetic tree, designed for the Pestalotiopsis spp. isolates that are pathogenic to pecan tree (Carya illinoinensis), according to the neighbor-joining statistical method derived from sequences of the ITS rDNA and $\beta$-tubulin regions, and based on 1,000 bootstrap replicates. The evolutionary distances were calculated using the Tamura-Nei parameter model. The numbers associated with the branches represent the bootstrap numbers. 
The isolates $\mathrm{P}_{3}, \mathrm{P}_{5}$, and $\mathrm{P}_{10}$ were identified as $P$. clavispora through ITS region sequencing. However, by $\beta$-tubulin gene sequencing, other species ( $P$. palmarum, $P$. crassiuscula, and $P$. virgatula) show high similarity with these isolates, and $\mathrm{P}_{10}$ also appears in the tree, separated by a major genetic distance, remaining clustered in another clade, which indicates some genetic difference. Therefore, the sequencing of the $\beta$-tubulin gene produced more questions regarding species identification, probably due to the restricted number of sequences deposited in databases.

$\mathrm{P}_{7}$ and $\mathrm{P}_{11}$ isolates were identified as $P$. cocculi through ITS sequencing, whereas $\mathrm{P}_{9}$ was identified as $P$. cocculi or $P$. vismiae, and the latter remained as an undefined species. With the sequencing of the $\beta$-tubulin gene, the same isolates were grouped in the same clade with $P$. cocculi and $P$. neglecta, confirming the identification by ITS sequencing, when these isolates were clustered with sequences of $P$. cocculi. It was also possible to observe, in this tree, that $\mathrm{P}_{9}$ remained in the same clade with the other $\mathrm{P}_{7}$ and $\mathrm{P}_{11}$ isolates.

Isolate $\mathrm{P}_{16}$ remained undefined for species level through $\beta$-tubulin gene sequencing, since it was clustered in a clade with sequences of different species of Pestalotiopsis (P. crassiuscula and P. palmarum). Therefore, the sequence of both genes, ITS and $\beta$-tubulin, was not sufficient for species definition of this isolate.

In the present study, the $\beta$-tubulin gene was not conclusive in identifying species of Pestalotiopsis, most likely due to the small number of gene sequences deposited for this genus in databases. The exception were the $\mathrm{P}_{7}, \mathrm{P}_{9}$, and $\mathrm{P}_{11}$ isolates, in which the sequence of the $\beta$-tubulin gene, already used in other studies with this genus (Hu et al., 2007; Liu et al., 2010), was used for identification by ITS. It is important to highlight that this fact does not suggest that the sequencing of this gene should be discarded, but rather encouraged to build a consistent database, which may further assist in the identification of species of the genus. Fungaro (2000) confirms this statement, reporting that large numbers of ITS sequences deposited in databases make this region more useful in the identification of fungal species.

\section{Conclusions}

1. Pestalotiopsis clavispora, P. cocculi, and Pestalotiopsis sp. are causal agents of pecan tree leaf spot.
2. Colony diameter is an important character for species differentiation of Pestalotiopsis spp.; however, it is important to evaluate the most possible characters of conidia, as number of cells, color of medium cells, conidia dimensions, and position and length of apical appendage.

3. The internal transcribed spacer (ITS) region sequencing is more informative and conclusive for the identification of Pestalotiopsis spp. than the sequencing of the $\beta$-tubulin gene.

\section{Acknowledgments}

To Coordenação de Aperfeiçoamento de Pessoal de Nível Superior (Capes), for the scholarship granted.

\section{References}

ALFENAS, A.C.; FERREIRA, F.A.; MAFIA, R.G.; GONÇALVES, R.C. Isolamento de fungos fitopatogênicos. In: ALFENAS, A.C.; MAFIA, R.G. (Ed.). Métodos em fitopatologia. Viçosa: Ed. da UFV, 2007. p.53-91.

ALMEIDA, W.A.B. de; NOGUEIRA, N. de L.; ROSSI, M.L.; RODRIGUEZ, A.P.M. Anatomia e ultra estrutura de embriões somáticos de pecan (Carya illinoinensis). Magistra, v.14, p.45-50, 2002.

AlveS, A.; CROUS, P.W.; CORREIA, A.; PHILlIPS, A.J.L. Morphological and molecular data reveal cryptic speciation in Lasiodiplodia theobromae. Fungal Diversity, v.28, p.1-13, 2008.

ANDRADE, E.M.; UESUGI, C.H.; UENO, B.; FERREIRA, M.A.S.V. Caracterização morfocultural e molecular de isolados de Colletotrichum gloeosporioides patogênicos ao mamoeiro. Fitopatolologia Brasileira, v.32, p.21-31, 2007. DOI: 10.1590/ S0100-41582007000100003.

BONITO, G.; BRENNEMAN, T.; VILGALYS, R. Ectomycorrhizal fungal diversity in orchards of cultivated pecan (Carya illinoinensis; Juglandaceae). Mycorrhiza, v.21, p.601-612, 2011. DOI: 10.1007/ s00572-011-0368-0.

CHEN, F.Y.; LU, L.M.; NI, H.Z.; WANG, Y.; WANG, Y.G.; LI, G.Q. First report of Pestalotiopsis mangiferae and P. vismiae causing twig dieback of Myrica rubra in China. Plant Disease, v.96, p.588, 2012. DOI: 10.1094/PDIS-12-11-1054-PDN.

CHUANQING, Z.; ZHIHONG, X.; PINLEI, S. Identification of the pathogen causing a new disease-nut black spot on Carya cathayensis. Plant Protection, v.36, p.160-162, 2010.

COUTINHO, H.L.; OLIVEIRA, V.M. de; MANFIO, G.P.; ROSADO, A.S. Evaluating the microbial diversity of soil samples: methodological innovations. Anais da Academia Brasileira de Ciências, v.71, p.491-503, 1999.

CRUZ, C.D. Programa Genes: diversidade genética. Viçosa: Ed. da UFV, 2008. 278p.

DHINGRA, O.D.; SINCLAIR, J.B. Basic plant pathology methods. $2^{\text {nd }}$ ed. Boca Raton: CRC Press, 1995. 448p.

Pesq. agropec. bras., Brasília, v.49, n.6, p.440-448, jun. 2014 DOI: 10.1590/S0100-204X2014000600005 
DOYLE, J.J.; DOYLE, J.L. Isolation of plant DNA from fresh tissue. Focus, v.1, p.13-15, 1991.

ESPINOZA, J.G.; BRICEÑO, E.X.; KEITH, L.M.; LATORRE, B.A. Canker and twig dieback of blueberry caused by Pestalotiopsis spp. and a Truncatella sp. in Chile. Plant Disease, v.92, p.1407-1414, 2008. DOI: 10.1094/PDIS-92-10-1407.

FALEIRO, F.G.; LUZ, E.D.M.N.; CERQUEIRA, A.O.; ROCHA, C.S.S. Uso de marcadores RAPD na classificação de isolados de Phytophthora spp. causadores da podridão parda do cacaueiro no Brasil. Fitopatologia Brasileira, v.28, p.312-315, 2003. DOI: 10.1590/S0100-41582003000300015.

FENG, Y.R.; LIU, B.S.; SUN, B.B. First report of leaf blotch caused by Pestalotiopsis clavispora on Rosa chinensis in China. Plant Disease, v.98, p. 1009, 2014. DOI: 10.1094/PDIS-01-14-0036-PDN.

FUNGARO, M.H.P. PCR na micologia. Biotecnologia, Ciência e Desenvolvimento, v.3, p.12-16, 2000.

HALL, T.A. BioEdit: a user-friendly biological sequence alignment editor and analysis program for Windows 95/98/NT. Nucleic Acids Symposium, v.41, p.95-98, 1999.

HU, H.L.; JEEWON, R.; ZHOU, D.Q.; ZHOU, T.X.; HYDE, K.D. Phylogenetic diversity of endophytic Pestalotiopsis species in Pinus armandii and Ribes spp.: evidence from rDNA and $\beta$-tubulin gene phylogenies. Fungal Diversity, v.24, p.1-22, 2007.

JEEWON, R.; LIEW, E.C.Y.; HYDE, K.D. Phylogenetic evaluation of species nomenclature of Pestalotiopsis in relation to host association. Fungal Diversity, v.17, p.39-55, 2004.

JEON, Y.H.; CHEON, W. First report of leaf blight of Japanese yew caused by Pestalotiopsis microspora in Korea. Plant Disease, v.98, p.691, 2014. DOI: 10.1094/PDIS-08-13-0821-PDN.

KEITH, L.M.; VELASQUEZ, M.E.; ZEE, F.T. Identification and characterization of Pestalotiopsis spp. causing scab disease of guava, Psidium guajava, in Hawaii. Plant Disease, v.90, p.16-23, 2006. DOI: 10.1094/PD-90-0016.

LAZAROTTO, M.; MUNIZ, M.F.B.; POLETTO, T.; DUTRA, C.B.; BLUME, E.; HARAKAVA, R.; POLETTO, I. First report of Pestalotiopsis clavispora causing leaf spot of Carya illinoensis in Brazil. Plant Disease, v.96, p.1826, 2012. DOI: 10.1094/ PDIS-07-12-0615-PDN

LIU, A.-R.; XU, T.; GUO, L.-D. Molecular and morphological description of Pestalotiopsis hainanensis sp. nov., a new endophyte from a tropical region of China. Fungal Diversity, v.27, p.23-36, 2007

LIU, A.R.; CHEN, S.C.; WU, S.Y.; XU, T.; GUO, L.D.; JEEWON, R.; WEI, J.G. Cultural studies coupled with DNA based sequence analyses and its implication on pigmentation as a phylogenetic marker in Pestalotiopsis taxonomy. Molecular Phylogenetics and Evolution, v.57, p.528-535, 2010. DOI: 10.1016/j. ympev.2010.07.017.

MAHADEVAKUMAR, S.; JANARDHANA, G.R. First report of Pestalotiopsis species causing leaf spot of cowpea (Vigna unguiculata) in India. Plant Disease, v.98, p.686, 2014. DOI: 10.1094/PDIS-02-13-0171-PDN.
MAHARACHCHIKUMBURA, S.S.N.; GUO, L.D.; CHUKEATIROTE, E.; BAHKALI, A.H.; HYDE, K.D. Pestalotiopsis - morphology, phylogeny, biochemistry and diversity. Fungal Diversity, v.50, p.167-187, 2011. DOI: 10.1007/ s13225-011-0125-x.

MICHEREFF, S.J.; NORONHA, M.A.; ROCHA JÚNIOR, O.M.; SILVA, J.A.; MIZUBUTI, E.S.G. Variabilidade de isolados de Alternaria brassicicola no Estado de Pernambuco. Fitopatologia Brasileira, v.28, p.656-663, 2003. DOI: 10.1590/ S0100-41582003000600012.

NATIONAL CENTER FOR BIOTECHNOLOGY INFORMATION. BLAST - basic local alignment search tool. 2012. Available at: <http://blast.ncbi.nlm.nih.gov>. Accessed on: 31 Aug. 2012a.

NATIONAL CENTER FOR BIOTECHNOLOGY INFORMATION. GenBank Home - National Center for Biotechnology Information. 2012. Available at: <http://www. ncbi.nlm.nnih.gov/genbank>. Accessed on: 31 Aug. 2012b.

PATEL, J.S.; NORMAN, D.; BRENNAN, M.; ALI, J.S. First report of elm canker caused by Pestalotiopsis mangiferae in the United States. Plant Disease, v.97, p.426, 2013. DOI: 10.1094/ PDIS-09-12-0865-PDN.

REIS JUNIOR, F.B.; REIS, V.M.; TEIXEIRA, K.R.S. Restrição do 16S-23S DNAr intergênico para avaliação da diversidade de Azospirillum amazonense isolado de Brachiaria spp. Pesquisa Agropecuária Brasileira, v.41, p.431-438, 2006. DOI: 10.1590/ S0100-204X2006000300009.

SOUZA, B.O. de; SOUZA, E.A. de; MENDES-COSTA, M.A. Determinação da variabilidade em isolados de Colletotrichum lindemuthianum por meio de marcadores morfológicos e culturais. Ciência e Agrotecnologia, v.31, p.1000-1006, 2007. DOI: 10.1590/S1413-70542007000400009.

TAMURA, K.; DUDLEY, J.; NEI, M.; KUMAR, S. MEGA4: molecular evolutionary genetics analysis (MEGA) software version 4.0. Molecular Biology and Evolution, v.24, p.1596-1599, 2007. DOI: $10.1093 / \mathrm{molbev} / \mathrm{msm} 092$.

TAYLOR, J.W.; JACOBSON, D.J.; KROKEN, S.; KASUGA, T.; GEISER, D.M.; HIBBETT, D.S.; FISHER, M.C. Phylogenetic species recognition and species concepts in fungi. Fungal Genetics and Biology, v.31, p.21-32, 2000. DOI: 10.1006/fgbi.2000.1228.

WEI, J.G.; XU, T. Pestalotiopsis kunmingensis, sp. nov., an endophyte from Podocarpus macrophyllus. Fungal Diversity, v.15, p.247-254, 2004.

WEI, J.-G.; XU, T.; GUO, L.-D.; LIU, A.R.; ZHANG, Y.; PAN, X.H. Endophytic Pestalotiopsis species associated with plants of Podocarpaceae, Theaceae and Taxaceae in Southern China. Fungal Diversity, v.24, p.55-74, 2007.

WHITE, T.J.; BRUNS, T.; LEE, S.B.; TAYLOR, J. Amplification and direct sequencing of fungal ribosomal RNA genes for phylogenetics. In: INNIS, M.A.; GELFAND, D.H.; SNINSKY, J.J.; WHITE, T.J. (Ed.). PCR protocols: a guide to methods and applications. New York: Academic Press, 1990. p.315-322.

Received on November 23, 2013 and accepted on May 27, 2014

Pesq. agropec. bras., Brasília, v.49, n.6, p.440-448, jun. 2014

DOI: $10.1590 / \mathrm{S} 0100-204 X 2014000600005$ 